\title{
PIOTR KLODKOWSKI
}

Uniwersytet Jagielloński

ORCID: 0000-0001-9273-8560

\author{
ANNA SIEWIERSKA-CHMAJ \\ Wyższa Szkoła Europejska im. ks. Józefa Tischnera \\ ORCID: 0000-0001-7943-3746
}

\section{O koncepcji ideologicznej kontrnarracji wobec przesłania fundamentalizmu islamskiego.}

\author{
Analiza wybranych przykładów radykalizacji i deradykalizacji \\ w Europie, Azji Południowej i na Bliskim Wschodzie
}

\author{
The concept of ideological counter-narrative \\ in response to the message of Islamic fundamentalism: \\ The analysis of selected examples of radicalisation \\ and de-radicalisation in Europe, the Middle East and South Asia
}

\begin{abstract}
The article discusses the issues of religious radicalisation and de-radicalisation in contemporary Islam. Its authors present complex phenomena of ideological, historical, cultural and political contexts of radicalisation processes, investigate the problem of distribution of radical propagandist materials among various Muslim communities around the world and analyse the consequences of ideological transformation of Islamic fundamentalism in selected European countries. In their analysis of ISIS recruitment policy they focus on Arie Kruglanski's research on cognitive closure and personal significance. The political concepts by Muhammad Iqbal and Muhammad Ali Jinnah are examined as examples of an ideological counter-narrative vis-à-vis fundamentalist philosophy, albeit with the proviso that their universal relevance is probably limited by the historical context of Pakistan. The authors conclude that the radicalisation propaganda has a global appeal as it has adopted a carefully selected group of universally recognised ideologues (Ibn Abd al-Wahhab, Abul A'la Maududi, Sayyid Qutb) but the recommended de-radicalisation processes should be rooted locally or regionally.
\end{abstract}

Keywords: radicalisation, de-radicalisation, fundamentalism, Islam, internet, counter-narrative Słowa kluczowe: radykalizacja, deradykalizacja, fundamentalizm, Islam, internet, kontrnarracja 
Choć zjawisko radykalizacji nie jest nowe, to szczególnie intensywnie zaczęto je analizować dopiero po serii zamachów terrorystycznych w państwach zachodnich, m.in. Stanach Zjednoczonych, Wielkiej Brytanii, Hiszpanii i Francji w latach 2001-2005. Pojęcie radykalizacja przestało być wtedy przedmiotem wyłącznie akademickich rozważań i weszło do szerokiego dyskursu publicznego, tracąc przy okazji na ostrości definicyjnej. Jednym z niewielu elementów powtarzających się w różnych ujęciach było stwierdzenie, że radykalizacja jest procesem, w wyniku którego jednostka lub grupa przyjmuje coraz bardziej ekstremalne poglądy. Pozostałe stwierdzenia najczęściej tylko zaciemniały zagadnienie, sprawiając, że radykalizacją wydawało się wszystko lub przeciwnie - zgoła nic. Niejasna czy wręcz błędna konceptualizacja utrudnia stawianie trafnych diagnoz i tak też się stało w przypadku pojęcia radykalizacja, wrzuconego do jednego worka z ekstremizmem politycznym, fundamentalizmem religijnym czy nawet terroryzmem islamskim ${ }^{1}$.

Spora część powstałych w tym czasie analiz koncentruje się na strukturalnych czynnikach radykalizacji (ubóstwie, wykluczeniu społecznym, wzroście nierówności etc.), bagatelizując lub pomijając inne mechanizmy warunkujące to zjawisko, szczególnie istotne, jeśli chcemy znaleźć uniwersalny ponadkulturowy wzór ilustrujący proces przekształcania normalnego człowieka $\mathrm{w}$ jednostkę gotową brutalnie zabijać niewinne osoby. Znalezienie takiego wzoru wydaje się niezwykle istotne, jeśli weźmiemy pod uwagę, że systematycznie zwiększa się liczba zamachów terrorystycznych dokonywanych przez tzw. samotne wilki, a więc pojedyncze osoby, które często nie należą do żadnych organizacji o charakterze ekstremistycznym, a jedynie zainspirowały się ich ideologią. Nadmierna koncentracja na politycznych, ekonomicznych czy religijnych przyczynach radykalizacji utrudnia dostrzeżenie, że jej wzrost następuje nie tylko wśród muzułmanów, ale generalnie jest tendencją globalną, obserwowaną w różnych grupach wyznaniowych i narodowych, w dużej mierze związaną z działaniem mediów, szczególnie zaś tzw. nowych mediów²

1 O problemach ze skonceptualizowaniem badań nad radykalizacją zob. m.in.: Jihadi terrorism and the radicalisation challenge. European and American experience, ed. R. Coolsaet, Ashgate, Farnham 2011; A. Kundnani, Radicalisation. The journey of a concept, „Race \& Class” 2012, vol. 54, No. 2; A.P. Schmid, Radicalisation, de-radicalisation, counter-radicalisation. A conceptual discussion and literature review, International Centre for Counter-Terrorism, Hague 2013 (ICCT Research Paper).

2 A.N. Awan, A. Hoskins, B. O'Loughlin, Radicalisation and media. Connectivity and terrorism in the new media ecology, Routledge, London 2011, s. 1-25; Z. Sawicka, Wptyw nowych mediów na przemiany polityczne wybranych państw Bliskiego Wschodu na przykładzie Arabskiej Wiosny, Warszawa 2017. 
Zauważyła to Komisja Kultury i Edukacji Parlamentu Europejskiego, przygotowując wskazówki do projektu rezolucji PE w sprawie zapobiegania radykalizacji oraz rekrutacji obywateli europejskich przez organizacje terrorystyczne (2015/2063(INI)). Autorzy raportu nie tylko zwrócili uwagę, że organizacje terrorystyczne wykorzystują do rozpowszechniania materiałów propagandowych i werbowania internet oraz media społecznościowe (co wydaje się sprawą dość oczywistą), ale wezwali też państwa członkowskie Unii Europejskiej do aktywnej walki z rozpowszechnianiem radykalnych treści i propagandy w internecie oraz wdrażania programów szerzenia wśród młodzieży wiedzy na temat nawoływania do nienawiści w internecie i związanych z tym zagrożeń. Komisja podkreśliła konieczność prowadzenia działań edukacyjnych mających na celu upowszechnianie umiejętności korzystania z mediów i internetu, zauważając, że należy rozwijać zarówno umiejętności krytycznego osądu wszystkich użytkowników środowiska cyfrowego, jak i technologie, które pomogą w kontrolowaniu i prewencyjnym zwalczaniu zjawiska radykalizacji. Choć w przygotowanym dokumencie nie mówi się wprost o pokoleniowych predyspozycjach generacji cyfrowej, spychających ją w kierunku różnego rodzaju ekstremizmów, to podkreśla się rolę kształcenia w zrozumieniu i zaakceptowaniu przez młodych ludzi różnic „opinii, przekonań, światopoglądów i stylów życia, z jednoczesnym poszanowaniem różnorodności i praworządności, w promowaniu krytycznego myślenia i właściwej oceny, aby umieli, w szczególności w kontekście internetu i mediów społecznościowych, zrozumieć rzeczywistość, odróżniać fakty od opinii, rozpoznawać propagandę oraz opierać się wszelkim formom indoktrynacji, mowy nienawiści i ekstremizmu internetowego"3.

\section{Radykalizacja, internet i nowe media}

Z wielu badań wynika, że to właśnie najmłodsi wyborcy odsuwają się od demokracji w kierunku różnego rodzaju izmów: populizmu, ekstremizmu, fundamentalizmu etc. ${ }^{4}$ Nieprzypadkowo chyba jest to ta sama grupa, która

3 Sprawozdanie w sprawie zapobiegania radykalizacji oraz rekrutacji obywateli europejskich przez organizacje terrorystyczne (2015/2063(INI)), „Parlament Europejski” [online], 3 XI 2015 [dostęp: 23 I 2018], dostępne w internecie: <http://www.europarl.europa.eu/sides/getDoc.do?pubRef=-//EP//TEXT+REPORT+A8-2015-0316+0+DOC+XML+V0//PL >.

4 O. Decker, J. Kiess, E. Brähler, Die enthemmte Mitte. Autoritäre und rechtsextreme Einstellung in Deutschland, Psychosozial-Verlag, [Leipzig 2016], dostępny także w internecie [dostęp: 27 I 2018]: <https://www.psychosozialverlag.de/pdfs/leseprobe/9783837926309. pdf >; WVS Wave 6 (2010-2014), World Values Survey [online, dostęp: 27 I 2018], dostępny w internecie: <http://www.worldvaluessurvey.org/WVSDocumentationWV6.jsp>; 
w największym stopniu korzysta z internetu oraz nowych mediów i tam też pozyskuje zdecydowaną większość informacji o świecie ${ }^{5}$. W tym kontekście łatwo zrozumieć, dlaczego władze Egiptu bardziej niż Państwa Islamskiego boją się milenialsów ${ }^{6}$, a George Soros na Forum Ekonomicznym w Davos w styczniu 2018 r. domagał się kontroli największych monopolistów z branży internetowej, m.in. Facebooka i Google'a, przestrzegając przed skoncentrowaniem siły i możliwości kształtowania uwagi ludzi w rękach kilku firm: „Musimy podjąć wysiłek potwierdzenia i obrony tego, co John Stuart Mill nazwał wolnością umysłu. Istnieje możliwość, że zagubieni ludzie dorastający w epoce cyfrowej będą mieli trudności z jej odzyskaniem”, a „ludźmi bez wolności ducha można łatwo manipulować"7. Czy obserwowany obecnie pochód różnego rodzaju zachowań skrajnych - nie tylko zresztą w wymiarze politycznym, ale i każdym innym - rzeczywiście jest związany z utratą wolności umysłu? I jak tę rzekomo utraconą wolność rozumieć?

Choć nietrudno podzielać zaniepokojenie Sorosa monopolistyczną pozycją korporacji internetowych, to już w proponowanej przez niego recepcie pobrzmiewa ta sama tęsknota za jakąś bliżej niesprecyzowaną wspaniałą przeszłością ludzkości i utraconym sensem, którą odnaleźć możemy i u zwolenników populizmu, i u ideologów współczesnego dżihadu. Naiwność takiego myślenia obnaża jednak bilans historii: stulecia wyniszczających wojen, zbrodnie przeciwko ludzkości, grabieżcza eksploatacja zasobów naturalnych - przykłady można mnożyć w nieskończoność. Szukanie klucza do rozwiązania współczesnych problemów w przeszłości jest jak gaszenie pożaru benzyną! Owszem, historia dostarcza nam wiedzy, ale bardziej o tym, czego robić nie należy, czego się trzeba z całą mocą wystrzegać. Który fragment naszej zbiorowej pamięci można celowo zmitologizować i użyć do politycznych celów? Którą postać historyczną łatwo postawić na piedestale, żeby się później za nim chować? Jakież to starożytne wartości należy odkurzyć, aby

Y. Mounk, R. S. Foa, The signs of deconsolidation, „Journal of Democracy” 2017, vol. 28, No. 1; S. Ul-Haq, ,Eure Gesetze interessieren uns nicht!” Undercover in europäischen Moscheen - wie Muslime radikalisiert werden, Orell Füssli Verlag, Zürich 2018.

5 H. Allcott, M. Gentzkow, Social media and fake news in the 2016 election, „Journal of Economic Perspectives" 2017, vol. 31, No. 2.

6 P. Schwartzstein, Egipska bomba demograficzna, „Newsweek”, 7 I 2018.

7 M. Oppenheim, Davos 2018: George Soros launches blistering attack on Trump „, The survival of our entire civilisation is at stake”, „Independent” [online], 26 I 2018 [dostęp: 26 I 2018], dostępny w internecie: <http://www.independent.co.uk/news/world/ europe/davos-2018-george-soros-launches-blistering-attack-on-trump-the-survival-of-our-entire-civilization-a8179311.html>. 
stały się narzędziem legitymizacji nowego porządku? Tak, w historii można szukać pułapek, w które wciąż wpadają człowiek i całe społeczeństwa, ale nie drogowskazów na przyszłość.

Nowe media mogą zubażać nie tyle naszą wolność (realną lub nie), co przede wszystkim - i to jest największe zagrożenie - naszą inteligencję. Amin Maalouf trafnie ujął ten problem w Rozregulowanym świecie, pisząc, że „przystać na ignorancję, to wyrzec się demokracji, to zredukować ją do pozorów"8.

Analizowanie zjawiska radykalizacji przez pryzmat pokoleniowej specyfiki generacji Y oraz wpływu internetu i nowych mediów pozwala uniknąć pułapki czyhającej na tych, którzy ulegną pokusie utożsamiania radykalizacji z islamem czy jakąkolwiek inną religią. Nie ma przy tym wątpliwości, że muzułmanie rzeczywiście są obecnie najbardziej zradykalizowaną grupą religijną, podobnie jak chrześcijanie (i to zarówno protestanci, katolicy, jak i prawosławni) byli najbardziej zradykalizowaną grupą w dziewiętnastowiecznej Europie. Czy analizowanie ówczesnych ruchów radykalnych, wzywających do gruntownych przemian społecznych, politycznych, obyczajowych, z których sporo zresztą stało się faktem (np. prawa wyborcze kobiet czy ośmiogodzinny dzień pracy), wnosi cokolwiek do badań nad współczesnym problemem radykalizmu? Wydaje się, że niewiele.

\section{Radykalizacja w obrębie środowisk muzułmańskich}

Alex S. Wilner i Claire-Jehanne Dubouloz zauważają, że radykalizacja muzułmanów przebiega na dwa różne sposoby. Przed zamachami na World Trade Center większość aktów terrorystycznych była przygotowana i przeprowadzona przez osoby zradykalizowane we własnym środowisku społeczno-kulturowym, gdzieś poza cywilizacją zachodnią, i jedynie ostatni akt w postaci zamachu wymierzony był przeciwko Zachodowi. Po 2001 r. zaczęło się rozprzestrzeniać zjawisko nazywane terroryzmem rodzimym, terroryzmem z własnego ogródka (ang. homegrown terrorism) - zdecydowanie bardziej niszczycielskie, najczęściej wymierzone w cywilów i stanowiące ogromne wyzwanie dla organów bezpieczeństwa ${ }^{9} . Z$ badań Edwina Bakkera wynika, że na dwustu dżihadystów, o których zebrano podstawowe informacje, 90 proc. było rezydentami krajów europejskich, a 60 proc. miało obywatelstwo

8 A. Maalouf, Rozregulowany świat, thum. W. Prażuch, Czytelnik, Warszawa 2011, s. 147.

9 A.S. Wilner, C.-J. Duboulozb, Homegrown terrorism and transformative learning. An interdisciplinary approach to understanding radicalization, „Global Change, Peace \& Security" 2010, vol. 22, No. 1, s. 33. 
któregoś z państw Europy ${ }^{10}$. Analiza życiorysów tzw. homegrown terrorists z lat 2005-2007 wyraźnie wskazuje, że ich radykalizacja oraz decyzja o aktywnym włączeniu się w działania terrorystyczne nastąpiły w Europie, przede wszystkim na skutek propagandy rozpowszechnianej w internecie i za pośrednictwem portali społecznościowych. Dość kontrowersyjną poznawczo tezę, z którą podejmiemy polemikę, stawia Magdalena Adamczuk:

Proces radykalizacji jest unikatowy dla każdej osoby, przez co trudno zdefiniować profil terrorysty i cechy charakterystyczne. W przechodzeniu przez poszczególne fazy radykalizacji trudno doszukać się logicznych ciągów zdarzeń, choć zazwyczaj proces rozpoczyna się wśród ludzi młodych, którzy szukają swojej tożsamości i często odnajdują ją poprzez identyfikację $\mathrm{z}$ ideologią islamizmu ${ }^{11}$.

Można zauważyć, że zarówno tempo, jak i zasięg radykalizacji zwiększają się wraz z dostępem do internetu i korzystaniem z nowych mediów, które pozwalają na łatwiejsze przekazywanie radykalnych treści ${ }^{12}$. Jest to tym prostsze, że działające w sieci techniki rekomendacji i kody śledzące internetową aktywność użytkowników pozwalają na ustalenie ich zainteresowań, a dzięki temu na personalizację podsuwanych treści, niezależnie czy chodzi o porady ogrodnicze, czy propagandę islamistyczną. Podsuwane wiadomości pozycjonowane w taki sposób, aby jak najbardziej odpowiadały konkretnemu użytkownikowi ${ }^{13}$.

\section{Ideologiczny, polityczny i społeczny kontekst radykalizacji}

Szeroka i niepodlegająca większej kontroli dystrybucja propagandy fundamentalistycznej $\mathrm{w}$ mediach społecznościowych jest $\mathrm{w}$ procesie radykalizacji potencjalnych odbiorców warunkiem koniecznym, ale naturalnie

10 E. Bakker, Jihadi terrorists in Europe. Their characteristics and the circumstances in which they joined the jihad, Netherlands Institute of International Relations, Hague 2006, s. 36-37.

11 M. Adamczuk, Rodzimy terroryzm jako zjawisko zagrażające bezpieczeństwu w Europie, „Bezpieczeństwo Narodowe” 2011, nr 1, s. 67.

12 Zauważył to m.in. Peter Bergen, autor raportu Jihad 2.0, zaprezentowanego przed Senacką Komisją Bezpieczeństwa Wewnętrznego i Spraw Rządowych USA. P. Bergen, Jihad 2.0: social media in the next evolution of terrorist recruitment, U.S. Government Publishing Office, Washington 2016, dostępny w internecie [dostęp: 30 I 2018]: <https:// archive.org/details/gov.gpo.fdsys.CHRG-114shrg95653>.

13 N. Leavitt, Recommendation technology. Will it boost e-commerce?, „Computer” 2006, vol. 39, s. 13-16, dostępny w internecie [dostęp: 30 I 2018]: <http://www.leavcom.com/ pdf/Recommend.pdf $>$. 
niewystarczającym. Istotne są konteksty polityczny oraz społeczno-kulturowy, które sprzyjają rozwojowi ideologii radykalizmu. Kwestie bezpieczeństwa wspólnoty wyznaniowej, obrony wartości wyznawanej religii bądź - jeszcze bardziej - postrzeganego zagrożenia kulturowo-religijnej tożsamości dość trudno precyzyjnie zdefiniować, stąd łatwość wykorzystywania ich do budowy skrajnie ideologicznej narracji przez ugrupowania fundamentalistyczne.

Raport przygotowany w 2013 r. przez Wissenschaftszentrums Berlin für Sozialforschung (WZB) na podstawie badań przeprowadzonych w sześciu państwach unijnych (m.in. we Francji i Niemczech) przedstawia całe spektrum poglądów współczesnych muzułmanów europejskich. Dwie trzecie tamtejszych wyznawców islamu twierdzi, że prawa religijne są ważniejsze aniżeli przepisy obowiązujące $\mathrm{w}$ danym państwie, a trzy czwarte nie dopuszcza pluralizmu w rozumieniu Koranu, uznając, że powinna istnieć wyłącznie jedna bezdyskusyjna interpretacja (dla kontrastu takie poglądy głosi odpowiednio 13 i 20 proc. europejskich chrześcijan). Aż 45 proc. muzułmańskich respondentów otwarcie deklaruje antysemityzm, a podobna liczba uznaje, że Zachód zamierza zniszczyć islam (wśród chrześcijan otwartych antysemitów jest 9 proc., a 23 proc. respondentów wyraża przekonanie, że islam zamierza zniszczyć Zachód). Autorzy raportu stawiają wniosek, że klasyczne idee fundamentalizmu znajdują bardzo podatny grunt wśród europejskich muzułmanów. Uderzająca jest zresztą sama teza zawarta w tytule raportu: ,[W Europie] Islamski fundamentalizm religijny jest szeroko rozpowszechniony"14. Trudno jednoznacznie wyjaśnić przyczyny takiego zjawiska, ale hipotetycznie można założyć, że dużą rolę odgrywa tutaj połączenie aktywnej polityki zagranicznej UE wobec krajów muzułmańskich z obowiązującą w Europie postreligijną koncepcją świeckiego państwa, co przez wyznawców islamu może być postrzegane jako zagrożenie, a nie szansa na kultywowanie religijnych wartości. Radykalna interpretacja społecznej pozycji własnej wspólnoty wyznaniowej i jej zagrożenia (realnego lub wyobrażonego) jest dodatkowo wzmacniana przekazem mediów społecznościowych, który łatwo przekracza granice państw i faktycznie przyczynia się do budowania ideologicznego sojuszu ponad etnicznymi i językowymi podziałami wśród muzułmanów. W takiej

14 Islamischer religiöser Fundamentalismus ist weit verbreitet, „Wissenschaftszentrum Berlin für Sozialforschung" [online], 9 XII 2013 [dostęp: 22 VIII 2018], dostępny w internecie: <https://www.wzb.eu/de/pressemitteilung/islamischer-religioeser-fundamentalismus-ist-weit-verbreitet>. Badaniami zostali objęci muzułmanie wywodzący się z tureckiej lub marokańskiej społeczności z Francji, Niemiec, Niderlandów, Belgii, Austrii i Szwecji. 
sytuacji ściślejsza współpraca i poczucie wspólnoty wyznaniowej między potomkami migrantów z Bangladeszu i Pakistanu w Wielkiej Brytanii, z Algierii czy Maroka we Francji oraz z Turcji w Niemczech, których wcześniej poza religią łączyło bardzo niewiele, nabiera nowego charakteru, staje się wręcz symbolem islamu ponad granicami, a to z kolei pozwala na skuteczniejszą dyfuzję materiałów propagandowych na całym kontynencie.

Mało prawdopodobne, aby kryzys migracyjny, który dotknął zachodnią i południową Europę, zmienił cokolwiek w podejściu badanej grupy muzułmanów, zwłaszcza że kolejne fale migracji przyczyniły się do wyborczych sukcesów partii i ugrupowań skrajnie prawicowych oraz doprowadziły do zmiany polityki migracyjnej partii głównego nurtu ${ }^{15}$. Należy w tym miejscu wyraźnie podkreślić kolejność wydarzeń: cytowane badania prowadzono przed największą falą migracyjną w 2015 r. i kolejnymi w latach późniejszych (co z kolei przyczyniło się do wzrostu popularności europejskich partii prawicowych), a nie po ich wystąpieniu. Innymi słowy: tendencje fundamentalistyczne wśród muzułmanów w badanych krajach UE były obecne od wielu lat, jeszcze przed prawicową radykalizacją części opinii publicznej na Starym Kontynencie, a zatem nie stanowią ideologicznej odpowiedzi na to zjawisko, aczkolwiek nie sposób też arbitralnie stwierdzić, że są jedną z ważniejszych przyczyn jego powstania.

Proces radykalizacji w Europie nie jest oczywiście zjawiskiem izolowanym, niezależnym od wydarzeń na Bliskim Wschodzie, w Afryce Północnej czy Azji Południowej. Łączy się mocno z fenomenem popularyzacji różnych odmian fundamentalizmu, którego początki możemy umieścić jeszcze przed drugą wojną światową: w Egipcie, gdzie założono organizację Braci Muzułmanów, oraz na obszarze Indii Brytyjskich, gdzie działał Abul A’la Maududi - jeden z najbardziej wpływowych ideologów całego ruchu ${ }^{16}$. Przez relatywnie długi czas fundamentaliści różnych opcji ideologicznych nie stanowili poważniejszego zagrożenia dla stabilności państw muzułmańskich (ani pośrednio dla Europy) i dopiero wydarzenia ostatnich trzydziestu

15 Zjawiska te stanowią również przedmiot zainteresowania ekspertów z Niemiec. Werner Krause i Tarik Abu-Chadi w ramach kolejnych projektów WZB analizują implikacje procesów imigracyjnych: W. Krause, T. Abu-Chadi, Radical right success and mainstream parties' anti-immigrant policy shifts, ,WZB Democracy Blog” [online], 17 VII 2018 [dostęp: 23 VIII 2018], dostępny w internecie: <https://democracy.blog.wzb.eu/2018/07/17/ radical-right-success-and-mainstream-parties-anti-immigrant-policy-shifts/>.

16 A. A'la Maududi, Risālah-e-Dīnīyat ['Traktat o religii’], Lahore 1932. Publikacja ukazała się też w języku polskim: S.A. A’la Al-Maududi, Zrozumieć islam, tłum. H. Szabanowicz, H. Sawafta, Gdańsk 1990. Por. szczegółową analizę koncepcji Maududiego: Seyyed V.R. Nasr, Mawdudi and the making of Islamic revivalism, Oxford University Press, Oxford 1996. 
lat pomogły im wydobyć się z niewielkiej ideowej niszy na główną scenę historii. Będący konsekwencją sowieckiej agresji dżihad w Afganistanie, rewolucja islamska w Iranie, wojna domowa w Algierii czy wreszcie interwencja Zachodu w Afganistanie i Iraku, a na koniec fenomen Arabskiej Wiosny ze wszystkimi jej konsekwencjami - wszystko to niebywale wzmocniło organizacyjnie, ideowo i finansowo skrajne ugrupowania muzułmańskie, które są w stanie narzucać własną wizję świata na podbitych (choćby tymczasowo) terytoriach w Iraku, Syrii, Afganistanie czy Pakistanie. Po drugiej stronie znajdują się autorytarne lub półautorytarne reżimy w Afryce Północnej i części Bliskiego Wschodu, które co prawda odrzucają radykalną interpretację religii, ale zachowują (albo usilnie próbują zachować) ścisłą kontrolę nad całą maszynerią państwa. Polityczny autorytaryzm to faktyczna cena za powstrzymywanie skrajnego nurtu fundamentalistycznego. Państwa Unii Europejskiej (przede wszystkim Francja i Wielka Brytania, a w mniejszym stopniu także Niemcy, Hiszpania czy Włochy) z konieczności rozwijają relacje z wybranymi reżimami autorytarnymi w poszczególnych częściach cywilizacji islamu, a tym samym legitymizują je. W skrajnych przypadkach zmuszone są interweniować zbrojnie (najczęściej we współpracy ze Stanami Zjednoczonymi), np. w Afganistanie, Iraku czy Libii. Takie działania stanowią dla organizacji fundamentalistycznych oczywisty pretekst do formułowania radykalnego przesłania, w którym celami wielopoziomowej agresji stają się: wybrane państwo, jego mieszkańcy, instytucje lub symbole (dochodzi np. do publicznego palenia flagi, niszczenia godła etc.). Dodatkowo przekaz wzmacnia się informacjami o rzeczywistej lub tylko wyimaginowanej dyskryminacji mniejszości muzułmańskiej w wybranym kraju europejskim lub - bardzo ogólnie - na całym Zachodzie, który prezentowany jest jako wróg islamu ${ }^{17}$.

\section{Psychologiczny wymiar procesów radykalizacyjnych}

Technologiczne możliwości skutecznej dystrybucji propagandy oraz konteksty polityczny i społeczno-kulturowy nie wystarczają do eksplikacji źródeł radykalizmu, zwłaszcza w wersji skrajnej - terroryzmu odwołującego się

17 Por. ewolucję radykalizmu w islamie i analizę języka propagandy: E. Sivan, Radykalny islam, thum. A. Kosior, Libron, Kraków 2005; G. Kepel, Święta wojna. Ekspansja i upadek fundamentalizmu muzułmańskiego, thum. K. Pachniak, Wydawnictwo Akademickie „Dialog", Warszawa 2003; B. Lewis, The crisis of Islam. Holy war and unholy terror, Modern Library, London 2003. Analiza kontekstu europejskiego znajduje się w tekście: P. Kłodkowski, Nowy spór o uniwersalia, czyli o wspólnocie muzutmańskiej w Europie XXI wieku, [w:] W pułapce wielokulturowości, red. A. Siewierska-Chmaj, Warszawa-Rzeszów 2016. 
do ideologii religijnej. Wskazywana w badaniach WZB rosnąca liczba fundamentalistów wśród europejskich muzułmanów niekoniecznie oznacza lawinowy przyrost osób odwołujących się do radykalizmu czynnego, akceptującego przelew krwi. Liczba osób zwerbowanych przez ISIS na terenie Europy prawdopodobnie nie przekroczyła pięciu tysięcy, ale szacunki podawane przez Europol w latach 2015-2017 mogą zostać ponownie zweryfikowane ${ }^{18}$. Jeżeli nawet założymy, że faktyczna liczba czynnych radykałów gotowych do stosowania metod terrorystycznych jest dwukrotnie lub trzykrotnie wyższa (jakkolwiek byłoby to szokujące), to i tak równa się promilowi całej wspólnoty muzułmańskiej na Starym Kontynencie. Naturalnie z punktu widzenia osób odpowiedzialnych za bezpieczeństwo państwa dane te muszą budzić niepokój i skłaniać do inicjowania odpowiednich działań.

Sprawą podstawową jest odpowiedź na pytanie o motywację poszczególnych ochotników ISIS, ich psychologiczny profil lub strukturę osobowości. Cytowana już Adamczuk sugeruje, że motywacja jest sprawą bardzo indywidualną, a proces radykalizacji może przebiegać u poszczególnych jednostek na wiele różnych sposobów. Oczywiście na pewnym poziomie ogólności trudno zanegować prosty fakt, że każda osoba ma swój niepowtarzalny charakter i typowy dla siebie sposób działania, tyle że w takiej sytuacji niemożliwe jest wyjaśnienie, dlaczego propaganda ISIS okazała się skuteczna i dlaczego użycie takich, a nie innych argumentów i obietnic potrafiło przekonać pewne grupy młodych mężczyzn (dużo rzadziej kobiet) do wstąpienia w szeregi organizacji terrorystycznej. Odwołujemy się w tym miejscu do badań i konkluzji Arie'ego Kruglanskiego, który przedstawił psychologiczny profil osoby zradykalizowanej, gotowej na użycie przemocy formalnie usprawiedliwianej wyznawaną ideologią. W referowanym artykule Kruglanski koncentruje się na fenomenie ISIS, ale warto przypomnieć, że jego badania dotyczyły także innych obszarów kulturowych, m.in. Sri Lanki, gdzie przez dziesięciolecia działała radykalna organizacja Tamilskich Tygrysów ${ }^{19}$. Kruglanski pisze:

18 Dane za: Up to 5,000 Europeans joined jihad, Europol chief says, „UE Observer” [online], 14 I 2015 [dostęp: 23 VIII 2018], dostępny w internecie: <https://euobserver.com/ news/127202>.

19 Por. A.W. Kruglanski, J. Belanger, M.G. Gelfand, R. Gunaratna, M. Hetiarrachchi, F. Reinares, E. A. Orehek, J. Sasota, K. Sharvit, Terrorism, a (self)love story. Redirecting the significance-quest can end violence, „American Psychologist” 2013, vol. 68, s. 559-575; A. W. Kruglanski, X. Chen, M. Dechesne, S. Fishman, E. Orehek, Fully committed. Suicide bombers'motivation and the quest for personal significance, „Political Psychology” 2009, vol. 30, issue 3, s. 331-357. Autorzy niniejszego artykułu przygotowują z prof. Arie'm Kruglanskim i jego współpracownikami z Uniwersytetu Marylandu projekt dotyczący procesów deradykalizacji w wybranych państwach muzułmańskich. 
[...] z psychologicznej perspektywy urok ekstremizmu odwołującego się do brutalnej przemocy opiera się na wykorzystaniu dwóch podstawowych ludzkich potrzeb: potrzeby domknięcia poznawczego (cognitive closure) i potrzeby osobistego znaczenia (personal significance). Potrzeba domknięcia oznacza dążenie do pewności [w życiu] i przełamanie [wszelkiej] dwuznaczności; to pragnienie, aby czuć się pewnym co do przyszłości, wiedzieć, co robić i dokąd się udać. Jest poszukiwaniem [właściwej] struktury i koherencji w swoich poglądach i przekonaniach ${ }^{20}$.

Kruglanski podkreśla, że obie potrzeby stanowią fundament ludzkiego doświadczenia, niemniej jednak intensywność ich realizowania w codziennej egzystencji zależy od kontekstu polityczno-społecznego. W czasach masowej migracji, zderzenia odmiennych kultur, recesji ekonomicznej oraz załamywania się dotychczasowego porządku w wielu państwach Bliskiego Wschodu i Afryki Północnej poczucie rosnącej niepewności i obaw o przyszłość własną, rodziny bądź wspólnoty (dodajmy: rzeczywistej lub ideowo postulowanej ${ }^{21}$ ) staje się dominującym uczuciem coraz większej liczby osób, zwłaszcza migrantów z obszarów cywilizacji islamu. Niespecjalnie zaskakuje, że potrzeba domknięcia poznawczego jawi się wówczas niczym psychologiczny balsam tworzący iluzję uporządkowanego świata wartości, niwelujący odczuwany ból otaczającego chaosu i bezsilności. Propozycja składana przez radykalne ugrupowania fundamentalistyczne dobrze wpisuje się w te potrzeby:

[...] kształtują światopogląd na sposób manichejski: charakteryzuje się on ostrymi dychotomiami i koniecznością wyraźnych wyborów: świat dobra kontra świat zła, święci kontra grzesznicy, porządek kontra chaos; to dwubarwny wszechświat malowany w czerni i bieli, niedopuszczający odcieni szarości. Ideologia fundamentalistyczna ustanawia wyraźne zależności między działaniami i konsekwencjami, oferuje przyszłość przewidywalną i pod pełną kontrolą. Taka perspektywa jest szczególnie fascynująca dla zdezorientowanych młodych ludzi na przejściowych etapach życia, którzy dryfują jak statki bez sterów i czują się rozdarci między sprzecznymi wymogami kulturowymi ${ }^{22}$.

20 A. W. Kruglanski, Psychology not theology. Overcoming ISIS'secret appeal, ,E-International Relations" [online], 28 X 2014 [dostęp: 26 VIII 2018], dostępny w internecie: <https:// www.e-ir.info/2014/10/28/psychology-not-theology-overcoming-isis-secret-appeal/>.

21 W materiałach propagandowych fundamentalistów często mówi się o tzw. prawdziwych muzułmanach, co oznacza po prostu ich rzeczywistych lub potencjalnych zwolenników. Pozostali, chociaż faktycznie stanowią dużą część wiernych, są odrzucani jako ci, którzy żyją w epoce współczesnej dżahilii, czyli religijnej ignorancji. Autorem koncepcji współczesnej dżahilii jest zmarły w 1966 r. Sajjid Kutb.

22 A. W. Kruglanski, Psychology... 
Koncepcja domknięcia poznawczego znakomicie wyjaśnia także rosnącą liczbę politycznie aktualizowanych mitów, które stają się zapleczem ideologii, szczególnie fundamentalistycznych ${ }^{23}$. Silna korelacja między potrzebą domknięcia a ekstremizmem podkreślona została $\mathrm{w}$ badaniach przeprowadzanych przez Departament Obrony USA oraz Narodową Fundację Nauki (National Science Foundation). Co istotne, ich wyniki nie są ograniczone do krajów muzułmańskich (Maroka i Palestyny), ale obejmują również Sri Lankę czy Irlandię Północną, gdzie jednak kwestie wewnętrznych konfliktów należą bardziej do przeszłości aniżeli teraźniejszości. Uwzględniając zatem w proponowanej eksplikacji elementy uniwersalizmu, należy podkreślić fakt, że o ile konflikty w Europie i Azji Południowej zostaną sklasyfikowane jako lokalne, to już problematyka ekstremizmu w poszczególnych krajach muzułmańskich ma charakter bardziej globalny i dotyczy obszarów Bliskiego Wschodu, Afryki Północnej (częściowo także części subsaharyjskiej) oraz - coraz częściej-samej Europy ${ }^{24}$.

Potrzeba domknięcia poznawczego powiązana jest ściśle ze wspomnianą potrzebą osobistego znaczenia. Kruglanski zwraca uwagę, że ISIS w swojej propagandzie oferuje potencjalnym bojownikom nagrody o wartości metafizycznej (a do pewnego stopnia także politycznej), które zaspokajają potrzeby psychologiczne. W walce przeciw niewiernym (do których często zalicza się także muzułmanów niepodzielających radykalnych poglądów) bojownicy zyskują status męczenników i bohaterów oraz miejsce w historii. To oni mają tworzyć nowy rozdział w dziejach islamu, stając się wręcz narzędziem w ręku Boga, a ich czyny mają jakoby zyskać akceptację wśród gorliwych wiernych. Rzecz jasna, w praktyce tak uwznioślony metafizycznie status potencjalnego bojownika jest nie do osiągnięcia w zwykłym, codziennym życiu, często naznaczonym biedą i brakiem perspektyw albo zwyczajną nudą płynącą z rutyny banalnych czynności wykonywanych od lat. Autorzy przesłania do przyszłych bojowników dżihadu korzystają ze sprawdzonych wzorców propagandowych, które chociaż formalnie odwołują się do metafizyki, to w rzeczywistości bazują na potrzebach psychologicznych, opisywanych już lata temu m.in. przez Abrahama Maslowa. Oficjalnie związany z Al-Kaidą Libijczyk Abu Jahja al-Libi jest autorem szeroko rozpowszechnianego apelu do wiernych w Algierii, w którym nawołuje do obalenia niewiernego rządu:

23 Por. A. Siewierska-Chmaj, Mit i ideologie polityczne, [w:] Mity w polityce. Funkcje i mechanizmy aktualizacji, Oficyna Wydawnicza „Aspra”, Warszawa 2016.

24 Już pod koniec XX w. kwestie regionalności i globalizacji fundamentalizmu poruszał Bassam Tibi. B. Tibi, Fundamentalizm religijny, tłum. J. Danecki, Państwowy Instytut Wydawniczy, Warszawa 1997. 
Ta ścieżka - a mam na myśli ścieżkę dżihadu - pomimo katastrof, cierpień, trudności i wszelkich form udręki, [które się na niej pojawiają], jest ścieżką, która podoba się Wszechmogącemu Bogu i jest oznaką najwyższego posłuszeństwa wobec Niego. Jest to dowód prawdziwej miłości Boga i rozróżniania między ludźmi uczciwości i wiary oraz ludźmi oszustwa i podstępu. Ścieżka dżihadu jest sposobem oczyszczenia szeregów muzułmanów i środkiem podtrzymania sztandaru prawdziwego monoteizmu oraz całkowitego eliminowania niewiary i wszelakiej profanacji ${ }^{25}$.

Tego rodzaju propagandowa enuncjacja wzmacniana jest dodatkowo przez odwołanie się do rzeczywistych lub nawet wyobrażonych cierpień muzułmanów: w Afganistanie bądź Iraku po interwencji Stanów Zjednoczonych, w Algierii, Libii czy Egipcie z powodu takiej lub innej polityki zagranicznej Francji, Wielkiej Brytanii albo Unii Europejskiej jako całości albo też wśród muzułmanów europejskich, którzy zdaniem propagandystów doświadczają prześladowań lub dyskryminacji. Celem ataku może być również rząd muzułmański - to przypadki Algierii i Egiptu, które rzekomo nie respektują nauk islamu i znajdują się pod wpływem zachodniej ideologii. W innej części swojego przesłania Abu Jahja al-Libi, skądinąd uznawany za uzdolnionego poetę i oratora, nawołuje:

Dżihad w Algierii jest dzisiaj waszą nadzieją i dzięki Najwyższemu wyzwoli [nas] od piekła niesprawiedliwych rządów, których więzienia są pełne młodzieży i dzieci, a nawet waszych kobiet ${ }^{26}$.

Obietnica zdobycia chwały i statusu męczennika łączy się tutaj z ideą boju o sprawiedliwość i pomszczeniem wszelkich krzywd, co naturalnie wzmacnia przekaz propagandowy. Ciekawym aspektem jest walka przeciwko współwyznawcom, widoczna np. w działaniach ISIS w Syrii i Iraku. Nie jest to co prawda żadne novum, albowiem idea walki wewnętrznej istnieje w islamie

25 Tłumaczenie apelu z języka arabskiego na angielski: Al-Qa'ida Abu-Yahya al-Libi calls on Algerians to fight against , infidel” government, 22 VI 2009, dostępny w internecie [dostęp: 22 VIII 2018]: <https://scholarship.tricolib.brynmawr.edu/bitstream/ handle/10066/4707/AYL20090622.pdf? sequence=4>. Na ten dokument powołuje się w swoim artykule Kruglanski. Niektóre sformułowania radykalnych fundamentalistów przywodzą na myśl frazy z Katechizmu rewolucyjnego Siergieja Nieczajewa, pochodzącego z zupełnie innej epoki i kultury. Paralele z ruchami rewolucyjnymi w Europie zob. V. Tismăneanu, Diabet w historii. Komunizm, faszyzm i inne lekcje wieku dwudziestego, tłum. K. Michałowicz, Państwowy Instytut Wydawniczy, Warszawa 2018, s. 151-153. Al-Qa'ida Abu-Yahya al-Libi calls on Algerians... 
niemal od początku, jednak w XX w. zyskała ona nowoczesną interpretację. Za ideologicznych arcywrogów skrajni fundamentaliści uważali twórcę Republiki Turcji Kemala Atatürka, króla Egiptu Faruka, a następnie prezydentów tego kraju: Gamala Abdela Nasera, Anwara as-Sadata i - w mniejszym stopniu - Husniego Mubaraka, którzy zdecydowanie występowali przeciw radykalizmowi Braci Muzułmańskich, aczkolwiek w sposób, który budził opór wśród samych Egipcjan. Muhammad Abd al-Salam Faradż - jeden z czołowych ideologów salafickich, szefujący radykalnemu ugrupowaniu Tanzim al-Dżihad i współodpowiedzialny za zamach na prezydenta Sadata - przedstawił swoje poglądy w brutalnie jasnych słowach: „Walka z wrogiem bliższym jest dużo ważniejsza aniżeli walka $\mathrm{z}$ wrogiem odległym. W prowadzonym dżihadzie będziemy więc przelewać krew muzułmanów, aż osiągniemy ostateczne zwycięstwo"27.

Kruglanski wskazuje na jeszcze jeden element propagandy ISIS, który stanowił część psychologicznego pakietu w procesie rekrutacji przyszłych bojowników. Chodzi o waloryzację najbardziej pierwotnych instynktów: agresji i popędu seksualnego, które miały być zaspokajane w szeregach organizacji. ISIS stworzył według niego ,dobrze naoliwioną maszynę seksualną” dla ochotników. Mogli oni korzystać z tzw. ośrodków małżeńskich, w których kobiety rejestrowały się (nierzadko przymuszane przemocą) celem poślubienia wybranego bojownika. Dzięki specjalnie sprokurowanym fatwom zalegalizowano także proceder korzystania z domów publicznych w Iraku, gdzie nadzorczyniami były ochotniczki z zagranicy, a ofiarami gwałtów - głównie niemuzułmanki. Według Nadii Murad tylko w 2014 r. z północnej prowincji Sindżar porwano około siedmiu tysięcy jezydek, które następnie brutalnie zmuszano do uprawiania seksu z członkami ISIS. Obietnice doznań seksualnych nie kończyły się na życiu doczesnym; fragmenty Koranu o męczennikach mających w raju dostęp do pięknych dziewic interpretowano dosłownie ${ }^{28}$.

Rzecz jasna, przemoc wobec kobiet i masowe gwałty towarzyszyły i nadal towarzyszą działaniom wojennym i terrorystycznym niemal w każdym miejscu na Ziemi i w każdej epoce historycznej. Warto jednakże zwrócić

27 Tekst ten: Al-Jihād: al-Farīda al Ghā'iba, podaje w swoim thumaczeniu Bernard Lewis: $\mathrm{B}$. Lewis, What went wrong? Western impact and Middle Eastern response, Harper Perennial, London 2003, s. 120.

28 Zob. np. opowieść jezydki Nadii Murad, która padła ofiarą przemocy ISIS: N. Murad, The last girl. My story of captivity and my fight against the Islamic State, Penguin Random House, New York 2017. Książka ukazała się również w polskim tłumaczeniu: taż, Ostatnia dziewczyna. O mojej niewoli $i$ walce z Państwem Islamskim, tłum. M. Koziej, Prószyński i S-ka, Warszawa 2018. 
uwagę na bardzo istotny element, który wyróżnia działania ISIS na tle innych. Seksualny dżihad usankcjonowany został zarówno metafizycznie, jak i prawnie, a tym samym zwalniał z ewentualnych wyrzutów sumienia co pobożniejszych muzułmanów. Oczywiście wydawane fatwy negowała zdecydowana większość muzułmańskich jurystów, tyle że w obrębie ISIS - zgodnie z zasadą domknięcia poznawczego - funkcjonowała i akceptowana była inna zasada interpretowania prawa islamu oraz jego metafizycznego przesłania, co pozwalało na nieskrępowane stosowanie przemocy na ogromną skalę.

Kruglanski wnioskuje, że relatywnie niewielka organizacja terrorystyczna odniosła sukcesy zarówno na polu militarnym, jak i psychologicznym, co pozwoliło właściwie skomponować całość propagandowego pakietu (ze swojej strony dodajmy jeszcze aspekt logistyczny i umiejętność bardzo dobrego wykorzystania mediów społecznościowych, bez których globalna rekrutacja nie byłaby w ogóle możliwa). Zasady domknięcia poznawczego i znaczenia osobistego w połączeniu z eksploatacją pierwotnych instynktów ludzkich okazały się niezwykle skuteczne przy werbowaniu ochotników i motywowaniu ich do stosowania nieznanej im prawdopodobnie wcześniej przemocy. Niewykluczone zatem, że nawet po ostatecznej klęsce ISIS będą one wykorzystywane przez kolejne organizacje fundamentalistyczne w różnych częściach globu.

\section{Proces deradykalizacji - zarys dzialania}

Deradykalizacja to niezwykle złożony proces, który zależy od uwarunkowań kulturowych, politycznych, ideologicznych oraz psychologicznych i powinien być realizowany na kilku zachodzących na siebie płaszczyznach. To, co będzie akceptowane np. w Pakistanie lub wśród europejskich Pakistańczyków, niekoniecznie zyska zrozumienie w Arabii Saudyjskiej czy Maroku. Oczywiście istnienie odmienności kulturowych w poszczególnych rejonach cywilizacji islamu bądź odrębności wybranych grup (np. wywodzących się z Azji Południowej muzułmanów w Bradford czy Arabów z Marsylii) nie oznacza, że wykluczamy pewną generalizację wywodów; wskazuje to raczej na wielość opcji, które mogą mieć zastosowanie w zależności od kontekstu polityczno-kulturowego.

Na politycznym poziomie makro, czyli całościowej polityki wobec obszaru pozaeuropejskiego, trudno rozsądnie spierać się z tezą, że niekontrolowana migracja z krajów muzułmańskich ma negatywny wpływ na stabilność i bezpieczeństwo państw unijnych. Względy humanitarne są naturalnie istotne, tyle 
że w żaden sposób nie powinny przesłaniać problemu ochrony życia i zdrowia własnych obywateli, co jest, a przynajmniej powinno być, priorytetem każdego rządu w świecie Realpolitik. To jedno z najtrudniejszych wyzwań, z którym w najbliższych latach będzie się musiała zmierzyć niemal cała UE.

Kolejnym problemem do przeanalizowania jest polityka zagraniczna państw unijnych wobec poszczególnych krajów muzułmańskich. Możliwości znaczącej korekty są tutaj dość ograniczone, nie sposób bowiem zawiesić lub nawet istotnie ograniczyć relacji z autorytarnymi rządami w Afryce Północnej czy na Bliskim Wschodzie, a więc $\mathrm{w}$ rejonach o strategicznym znaczeniu dla Europy, chociaż głównie południowej i zachodniej. Warto jednakże dobitnie podkreślać fakt, że Zachód - jako całość - ma coraz mniejszy wpływ na wewnętrzną sytuację w tym rejonie (lub wręcz nie ma żadnego) i nie może odpowiadać za brutalne działania tamtejszych rządów. Protesty dyplomatyczne wobec łamania praw człowieka albo ograniczone sankcje ekonomiczne powinny stanowić jedyną opcję. Dramatyczne konsekwencje interwencji zbrojnej w Libii, a wcześniej w Iraku, powinny być świadectwem, że opcja militarna doprowadziła do całkowitej lub częściowej dezintegracji obydwóch państw i w żaden sposób nie poprawiła bezpieczeństwa w regionie. Interwencja w Iraku i późniejsze walki wewnętrzne kosztowały życie niemal dwustu tysięcy osób, przy czym wielu muzułmanów obarcza odpowiedzialnością głównie Stany Zjednoczone i ich sojuszników. Nawet jeżeli nie w pełni zgadzamy się z takim rozumowaniem, to musimy uwzględnić, że narracja o odpowiedzialności Zachodu stanowi mocny argument $\mathrm{w}$ propagandzie organizacji fundamentalistycznych ${ }^{29}$.

W miarę duże możliwości działania z radykalnymi odłamami islamu dawałaby naszym zdaniem wojna ideologiczna - propagowanie kontrnarracji, której struktura i treść wywodziłyby się z cieszących się autorytetem środowisk muzułmańskich, niekoniecznie zamieszkujących Europę. Przytoczmy w tym miejscu mało znany przykład Pakistanu, jednego z największych państw muzułmańskich, mającego dodatkowo negatywny wizerunek w Europie i Stanach Zjednoczonych. Działania deradykalizacyjne zostały tam zainicjowane przez rząd i armię w ramach akcji „Zarb-e-Azb”, aczkolwiek ich kierunek i dalsze losy zależą od obecnej sytuacji politycznej. W uproszczeniu chodzi o propagowanie ideologii islamu (a tym samym ideologii samego państwa) opracowanej przez ojców założycieli - Muhammada Alego Jinnaha i Muhammada

29 Dane z raportu: Documented civilian deaths from violence, „Iraq Body Count” [online, dostęp: 28 VIII 2018], dostępny w internecie: <https://www.iraqbodycount.org/database/>. 
Iqbala. Stoi ona w kontrze do fundamentalistycznych konceptów w wersji Maududiego, gorliwie rozpowszechnianych w kraju od czasów prezydentury Muhammada Zii ul-Haqa ${ }^{30}$. Uznawany za jednego z największych muzułmańskich filozofów XX w. Iqbal jest autorem koncepcji liberalnego islamu, w której akceptuje system demokratyczny (aczkolwiek nie w wersji anglosaskiej czy szerzej: zachodniej) i odrzuca filozofię przemocy usprawiedliwianej przesłaniem religijnym ${ }^{31}$. Jinnah jest natomiast faktycznym twórcą współczesnego Pakistanu, który miał być w jego zamyśle państwem tolerancyjnym i do pewnego stopnia otwartym na idee wywodzące się spoza cywilizacji islamu. Do politycznego i religijnego dziedzictwa obydwóch ikonicznych postaci odwołuje się m.in. obecny premier Pakistanu Imran Khan, szef partii Pakistan Tehreek-e-Insaf, skądinąd absolwent Oxfordu i kiedyś czołowy gracz krykieta na świecie. Trudno przewidzieć, jakich kształtów nabierze ten ideologiczny spór, niemniej warto przeanalizować stosowany tutaj model narracyjny. Z jednej strony mamy ideologię dobrze umocowaną we współczesnym rozumieniu islamu, opracowaną przez postacie mające status polityczno-religijnych ikon, z drugiej natomiast - fundamentalistyczną wersję religii, kojarzoną (chociaż nie zawsze wprost) z Abu A’la Maududim. Jeżeli mająca silną legitymację tradycji bardziej liberalna interpretacja islamu będzie propagowana we właściwy sposób i przy pomocy współczesnych autorytetów religijnych, ma szansę stopniowo zredukować wpływy ideologii przemocy i fanatyzmu symbolizowanej przez odłamy miejscowych talibów, którzy zagrażają stabilności państwa. Jest to zadanie wymagające wielu lat pracy, ale możliwe do zrealizowania pod warunkiem uzyskania dużej wiarygodności przez tych, którzy są za nie odpowiedzialni.

Powyższy model cechują naturalnie pewne ograniczenia. O ile ideologia fundamentalizmu ma zasięg globalny i często odwołuje się do tych samych autorytetów religijnych, jak Ibn Tajmijja, Muhammad ibn Abd al-Wahhab, Sajjid Kutb czy wspomniany Maududi, to proponowana kontrnarracja ma najczęściej charakter lokalny, gdyż takie ikony jak Iqbal i Jinnah cieszyłyby

30 O ile militarny aspekt „Zarb-e-Azb” został wszechstronnie zilustrowany w mediach i oficjalnych dokumentach, to już działania deradykalizacyjne na poziomie ideologicznym i psychologicznym nadal są przedmiotem szerokiej dyskusji. Biorą w niej udział nie tylko instytucje państwowe, ale także cieszące się autorytetem organizacje religijne, np. Muslim Institute, z którym współpracują autorzy artykułu.

31 Chodzi tu przede wszystkim o publikację: M. A. Iqbal, Islam as an ethical and political ideal, Islamic Book Service, Lahore 1977. Szczegółowo opracowana wizja współczesnego islamu znajduje się $\mathrm{w}$ traktacie: tenże, The reconstruction of religious thought in Islam, Iqbal Academy Pakistan, Lahore 1989. 
się autorytetem w samym Pakistanie (ewentualnie wśród społeczności muzułmańskiej w Wielkiej Brytanii), ale nie zyskałyby zrozumienia w Kuwejcie, Omanie czy Maroku, gdzie są mało znane albo mało wiarygodne ${ }^{32}$. W przypadku Unii Europejskiej jako całości zadanie budowania kontrnarracji powinno spoczywać na lokalnych społecznościach muzułmańskich i obdarzanych szacunkiem teologach (pod umiarkowanym nadzorem państwa); uznajemy za mało prawdopodobne, by udało się stworzyć koncept paneuropejski, jednakowo wiarygodny dla zróżnicowanych językowo i etnicznie europejskich wspólnot islamu. Wspólnym dla wszystkich celem perspektywicznym powinno być natomiast sformułowanie filozofii wielowymiarowego islamu europejskiego, kompatybilnego ideowo z systemem demokracji liberalnej. Rola państwa w całym procesie powinna być znacząca, chociaż w niektórych obszarach celowo wstrzemięźliwa. Oficjalne akceptowanie przesłania kontrnarracji i jej autorytetów jest koniecznością, tyle że świeckie instytucje powinny zostawić w tym obszarze sporo miejsca do interpretacji wyselekcjonowanym ulemom, w przeciwnym razie cały proces nie zyska koniecznej wiarygodności wśród wiernych. Tworzona kontrnarracja powinna uwzględniać kwestie poruszane przez Kruglanskiego: w dużym stopniu zaspokajać potrzebę domknięcia poznawczego wiernych (cognitive closure) i ich osobistego znaczenia (personal significance). Konieczna byłaby tutaj współpraca ulemów i doświadczonych psychologów (najlepiej muzułmanów lub przynajmniej współpracujących ze wspólnotami muzułmańskimi), którzy specjalizują się w analizie zjawisk radykalizmu. Do zadań państwa demokratycznego należy też pomoc przy szerokiej dystrybucji całej kontrnarracji i skutecznym blokowaniu przepływu treści radykalnych w mediach społecznościowych. W świecie wolności słowa i swobodnego przepływu informacji wydawać się to może zadaniem niewykonalnym, tyle że brak działań w tym obszarze może skutkować porażką całego projektu. I wreszcie uwaga końcowa: umiarkowanie aktywna rola oficjalnych instytucji w procesie tworzenia kontrnarracji o charakterze wyznaniowym budzi niedobre skojarzenia wśród niemałej liczby Europejczyków przywiązanych do zasady neutralności światopoglądowej państwa. Za wzorcową uznawana jest brytyjska czy może raczej anglosaska filozofia niewtrącania się w jakiekolwiek problemy wyznaniowe, które pozostawia się do rozstrzygnięcia wspólnotom religijnym. Problem w tym,

32 Warto wspomnieć, że w pracy Islam as an ethical and political ideal Iqbal krytykował każdy system władzy dziedzicznej, stąd też jego analizy struktury państwa opartego na filozofii islamu nie będą przyjmowane z entuzjazmem przez władze państw o ustroju monarchicznym, np. Arabii Saudyjskiej, Maroka czy Omanu. 
że właśnie takie podejście, w większym lub mniejszym stopniu akceptowane w wielu krajach unijnych, umożliwiło skuteczne propagowanie w Europie zglobalizowanego przesłania fundamentalizmu, najczęściej w wersji wahhabickiej, co pośrednio potwierdzają cytowane badania WZB i późniejsze Pew Research Center (PRC). Obecnie UE zamieszkuje dwudziestopięciomilionowa społeczność wyznawców islamu, a według jednego z trzech scenariuszy opracowanych przez PRC do roku 2050 ich liczba może się potroić, przy czym w samych Niemczech oznaczałoby to wzrost z 6,1 proc. całości populacji w 2016 r. do 19,7 proc. trzydzieści cztery lata później ${ }^{33}$. Brak odpowiednich działań Unii sprawi, że stopniowa, aczkolwiek nierównomiernie rozłożona radykalizacja całej społeczności muzułmańskiej prowadzić będzie do coraz większej akceptacji społecznej dla radykalizmu skrajnej prawicy, a to z kolei przyczyni się, jak zakładamy, do ostatecznej dezintegracji Unii Europejskiej. Polityczną ripostą na sztuczne zacieranie granic kulturowych często bywa wznoszenie ideologicznych murów.

Taki scenariusz, choć może trudny do wyobrażenia dzisiaj, realizowany byłby w sytuacji braku zdecydowanych działań deradykalizacyjnych. Ich powyższy opis wraz z analizą fenomenu radykalizacji niech będzie uznany za skromny wkład polskich akademików w proces rzeczywistej konsolidacji Unii Europejskiej.

\section{Bibliografia}

Adamczuk M., Rodzimy terroryzm jako zjawisko zagrażajace bezpieczeństwu w Europie, „Bezpieczeństwo Narodowe” 2011, nr 1.

Allcott H., Gentzkow M., Social media and fake news in the 2016 election, „Journal of Economic Perspectives" 2017, vol. 31, No. 2.

Awan A. N., Hoskins A., O'Loughlin B., Radicalisation and media. Connectivity and terrorism in the new media ecology, Routledge, London 2011.

Bakker E., Jihadi terrorists in Europe. Their characteristics and the circumstances in which they joined the jihad, Netherlands Institute of International Relations, Hague 2006.

Bergen P., Jihad 2.0: social media in the next evolution of terrorist recruitment, U. S. Government Publishing Office, Washington 2016, dostępny w internecie [dostęp: 30 I 2018]: <https:// archive.org/details/gov.gpo.fdsys.CHRG-114shrg95653>.

33 Por. problematykę trzech scenariuszy dotyczących społeczności muzułmańskiej w Europie, analizowaną w raporcie Pew Research Center: M. Lipka, Europe's Muslim population will continue to grow - but how much depends on migration, „Pew Research Center" [online], 4 XII 2017 [dostęp: 26 VIII 2018], dostępny w internecie: <http:// www.pewresearch.org/fact-tank/2017/12/04/europes-muslim-population-will-continue-to-grow-but-how-much-depends-on-migration/>. 
Decker O., Kiess J., Brähler E., Die enthemmte Mitte. Autoritäre und rechtsextreme Einstellung in Deutschland, Psychosozial-Verlag, [Leipzig 2016], dostępny także w internecie [dostęp: 27 I 2018]: <https://www.psychosozialverlag.de/pdfs/leseprobe/9783837926309.pdf>.

Documented civilian deaths from violence, „Iraq Body Count” [online, dostęp: 28 VIII 2018], dostępny w internecie: <https://www.iraqbodycount.org/database/>.

Haq, Ul- S., ,Eure Gesetze interessieren uns nicht!” Undercover in europäischen Moscheenwie Muslime radikalisiert werden, Orell Füssli Verlag, Zürich 2018.

Iqbal M.A., Islam as an ethical and political ideal, Islamic Book Service, Lahore 1977.

Iqbal M. A., The reconstruction of religious thought in Islam, Iqbal Academy Pakistan, Lahore 1989.

Islamischer religiöser Fundamentalismus ist weit verbreitet, „Wissenschaftszentrum Berlin für Sozialforschung" [online], 9 XII 2013 [dostęp: 22 VIII 2018], dostępny w internecie: $<$ https://www.wzb.eu/de/pressemitteilung/islamischer-religioeser-fundamentalismus-ist-weit-verbreitet>.

Jihadi terrorism and the radicalisation challenge. European and American experience, ed. R. Coolsaet, Ashgate, Farnham 2011.

Kepel G., Święta wojna. Ekspansja i upadek fundamentalizmu muzutmańskiego, tłum. K. Pachniak, Wydawnictwo Akademickie „Dialog”, Warszawa 2003.

Kłodkowski P., Nowy spór o uniwersalia, czyli o wspólnocie muzułmańskiej w Europie XXI wie$k u$, [w:] W pułapce wielokulturowości, red. A. Siewierska-Chmaj, Warszawa-Rzeszów 2016.

Krause W., Abu-Chadi T., Radical right success and mainstream parties' anti-immigrant policy shifts, „WZB Democracy Blog” [online], 17 VII 2018 [dostęp: 23 VIII 2018], dostępny w internecie: <https://democracy.blog.wzb.eu/2018/07/17/radical-right-successand-mainstream-parties-anti-immigrant-policy-shifts/>.

Kruglanski A. W., Psychology not theology. Overcoming ISIS' secret appeal, „E-International Relations" [online], 28 X 2014 [dostęp: 26 VIII 2018], dostępny w internecie: <https:// www.e-ir.info/2014/10/28/psychology-not-theology-overcoming-isis-secret-appeal/>.

Kruglanski A.W., Belanger J., Gelfand M.G., Gunaratna R., Hetiarrachchi M., Reinares F., Orehek E.A., Sasota J., Sharvit K., Terrorism, a (self)love story. Redirecting the significance-quest can end violence, „American Psychologist” 2013, vol. 68.

Kruglanski A.W., Chen X., Dechesne M., Fishman S., Orehek E., Fully committed. Suicide bombers'motivation and the quest for personal significance, „Political Psychology” 2009, vol. 30 , issue 3 .

Kundnani A., Radicalisation. The journey of a concept, „Race \& Class” 2012, vol. 54, No. 2.

Leavitt N., Recommendation technology. Will it boost e-commerce?, „Computer” 2006, vol. 39, dostępny w internecie [dostęp: 30 I 2018]: <http://www.leavcom.com/pdf/Recommend.pdf $>$.

Lewis B., The crisis of Islam. Holy war and unholy terror, Modern Library, London 2003.

Lewis B., What went wrong? Western impact and Middle Eastern response, Harper Perennial, London 2003.

Lipka M., Europe's Muslim population will continue to grow - but how much depends on migration, „Pew Research Center” [online], 4 XII 2017 [dostęp: 26 VIII 2018], dostępny w internecie: <http://www.pewresearch.org/fact-tank/2017/12/04/europes-muslim-population-will-continue-to-grow-but-how-much-depends-on-migration/>.

Maalouf A., Rozregulowany świat, thum. W. Prażuch, Czytelnik, Warszawa 2011.

Maududi A. A'la, Risālah-e-Dīnīyat ['Traktat o religii'], Lahore 1932.

Maududi, Al- S. A. A’la, Zrozumieć islam, thum. H. Szabanowicz, H. Sawafta, Gdańsk 1990. 
O koncepcji ideologicznej kontrnarracji wobec przesłania fundamentalizmu islamskiego...

Mounk Y., Foa R. S., The signs of deconsolidation, „Journal of Democracy” 2017, vol. 28, No. 1. Murad N., The last girl. My story of captivity and my fight against the Islamic State, Penguin Random House, New York 2017.

Murad N., Ostatnia dziewczyna. O mojej niewoli i walce z Państwem Islamskim, tłum. M. Koziej, Prószyński i S-ka, Warszawa 2018.

Nasr V.R., Seyyed, Mawdudi and the making of Islamic revivalism, Oxford University Press, Oxford 1996.

Oppenheim M., Davos 2018: George Soros launches blistering attack on Trump - , The survival of our entire civilisation is at stake”, „Independent” [online], 26 I 2018 [dostęp: 26 I 2018], dostępny w internecie: <http://www.independent.co.uk/news/world/europe/ davos-2018-george-soros-launches-blistering-attack-on-trump-the-survival-of-our-entire -civilization-a8179311.html>.

Al-Qa'ida Abu-Yahya al-Libi calls on Algerians to fight against ,infidel” government, $22 \mathrm{VI}$ 2009, dostępny w internecie [dostęp: 22 VIII 2018]: <https://scholarship.tricolib.brynmawr.edu/bitstream/handle/10066/4707/AYL20090622.pdf?sequence=4>.

Sawicka Z., Wpływ nowych mediów na przemiany polityczne wybranych państw Bliskiego Wschodu na przyktadzie Arabskiej Wiosny, Warszawa 2017.

Schmid A.P., Radicalisation, de-radicalisation, counter-radicalisation. A conceptual discussion and literature review, International Centre for Counter-Terrorism, Hague 2013 (ICCT Research Paper).

Schwartzstein P., Egipska bomba demograficzna, „Newsweek”, 7 I 2018.

Siewierska-Chmaj A., Mit i ideologie polityczne, [w:] Mity w polityce. Funkcje i mechanizmy aktualizacji, Oficyna Wydawnicza „Aspra”, Warszawa 2016.

Sivan E., Radykalny islam, tłum. A. Kosior, Libron, Kraków 2005.

Sprawozdanie w sprawie zapobiegania radykalizacji oraz rekrutacji obywateli europejskich przez organizacje terrorystyczne (2015/2063(INI)), „Parlament Europejski” [online], 3 XI 2015 [dostęp: 23 I 2018], dostępne w internecie: <http://www.europarl.europa.eu/sides/ getDoc.do?pubRef=-//EP//TEXT+REPORT+A8-2015-0316+0+DOC+XML+V0//PL $>$.

Tibi B., Fundamentalizm religijny, tłum. J. Danecki, Państwowy Instytut Wydawniczy, Warszawa 1997.

Tismăneanu V., Diabet w historii. Komunizm, faszyzm i inne lekcje wieku dwudziestego, thum. K. Michałowicz, Państwowy Instytut Wydawniczy, Warszawa 2018.

Up to 5,000 Europeans joined jihad, Europol chief says, „UE Observer” [online], 14 I 2015 [dostęp: 23 VIII 2018], dostępny w internecie: <https://euobserver.com/news/127202>.

W pułapce wielokulturowości, red. A. Siewierska-Chmaj, Warszawa-Rzeszów 2016.

Wilner A.S., Duboulozb C.-J., Homegrown terrorism and transformative learning. An interdisciplinary approach to understanding radicalization, „Global Change, Peace \& Security” 2010, vol. 22, No. 1.

WVS Wave 6 (2010-2014), „World Values Survey” [online, dostęp: 27 I 2018], dostępny w internecie: <http://www.worldvaluessurvey.org/WVSDocumentationWV6.jsp>. 